Marquette University

e-Publications@Marquette

Theology Faculty Research and Publications

Theology, Department of

$1-1-2000$

\title{
Secrets of Creation in 2 (Slavonic) Enoch
}

Andrei Orlov

Marquette University, andrei.orlov@marquette.edu

Published version. Henoch, Vol. 22, No. 1 (2000): 45-62. Publisher Link. (C) 2000 Morcelliana. Used with permission. 
Andrei A. Orlov

\section{SECRETS OF CREATION IN 2 (SLAVONIC) ENOCH}

[ published in Henoch 22 (2000) 45-62]

(This paper requires the fonts $\underline{\text { SP Tiberian, SP Ionic, SP Atlantic and Kirillica Wincyr) }}$

Enoch was found blameless, and he walked with the Lord and he was taken away a sign of $\mathrm{t}(\mathrm{d}$ for generations

(Cairo Geniza Ms. B Sirah 44:16)

.... the learned savant

who guards the secrets of the great gods.

(Tablet from Nineveh, 19)

\section{The Secrets}

The notion of "secrets" occupies a distinct place in 2 (Slavonic) Enoch. The importance of this terminology is highlighted by its prominent position in the title of the book. While various manuscripts of 2 Enoch are known under different titles, most of them ${ }^{[1]}$ include the word "secrets." [2] In some of these titles the term is connected with Enoch's books - "The Secret Books of Enoch." [3] In other titles "secrets" are linked either to God ("The Book[s] [called] the Secrets of God, a revelation to Enoch") ${ }^{[4]}$ or to Enoch himself ("The Book of the Secrets of Enoch"). ${ }^{[5]}$ This consistency in the use of the term "secrets," in spite of its varied attribution to different subjects, may indicate that the authors and/or the transmitters of the text viewed the motif of "secrets" as a central theme of the apocalypse. The purpose of this article is to call attention to some details of this theme in 2 Enoch.

\section{The Story}

Despite the prominent role the word "secrets" seems to play in the titles of the book, it occurs, quite unexpectedly, only three times in the main body of 2 Enoch, twice in chapter 24 and once in chapter 36. It is not, however, coincidental that the term is found in this section of the book. Chapters 24-36 of 2 Enoch can be viewed as the climax of angelic and divine revelations to Enoch during his celestial tour. From these chapters we learn that Enoch, previously described to have been "placed" into the clothes of glory and instructed by the archangel Vereveil, was called by the Lord. The book tells that the Lord decided to reveal to Enoch the secrets of His creation, which he never explained even to his angels. Further the term "secrets" is applied only to this account of God's creation, conveyed to Enoch by the Lord himself, "face to face." $[6]$ The content of these revelations includes the following details: 
1. Prior to the Creation the Lord decided to establish the foundation of all created things;

2. He commanded one of the invisible "things" to come out of the very lowest darkness and become visible;

3. By Lord's command a primordial "great aeon," bearing the name Adoil, descended and, disintegrating himself, revealed all creation which the Lord "had thought up to create;"[7]

4. The Lord created a throne for himself. He then ordered to the light to become the foundation for the highest things;

5. The Lord called out the second aeon, bearing the name Arukhas, who became the foundation of the lowest things;

6. From the waters the Lord "hardened big stones," establishing the solid structure above the waters;

7. The Lord fashioned the heavens and the sun;

8. From fire the Lord created the armies of "the bodiless ones;"

9. The Lord created vegetation, fish, reptiles birds and animals;

10. The Lord created man.

While the general structure of the account of creation appears to be similar in the shorter and the longer recension, the latter offers a lengthy account dedicated to Adam's creation and his transgression.

Let it be also noted that the notion of "secrets" sets symbolic boundaries for the story of creation; it begins and closes the account of creation. In chapter 24 the Lord tells Enoch that he wants to instruct him in His secrets. In some manuscripts of the longer recension, chapter 24 even has a specific heading, "About the great secrets of God, which God revealed and related to Enoch; and he spoke with him face to face. ${ }^{[8]}$ In chapter 36, which serves as a conclusion of the Lord's instruction, the Lord promises Enoch the role of the expert in His secrets--"Because a place has been prepared for you, and you will be in front of my face from now and forever. And you will be seeing my secrets ${ }^{[9]} \ldots . . .[10]$

\section{Expert in Secrets}

The tradition about Enoch as an expert in God's secrets does not begin in 2 Enoch. Already in the earliest Enochic bookletes of 1 (Ethiopic) Enoch, the knowledge and the revelation of secrets become major functions of the elevated Enoch. ${ }^{[11]}$ Later Enochic traditions also emphasize the role of Enoch as the "Knower of Secrets" (Myzr (dwy). According to 3 Enoch, Enoch-Metatron is able to behold "deep secrets and wonderful mysteries." ${ }^{[121}$ In this Merkabah text Metatron is also responsible for transmitting the highest secrets to the Princes under him, as well as to humankind. H. Kvanvig observes that "in Jewish tradition Enoch is primarily portrayed as a primeval sage, the ultimate revealer of divine secrets."[13]

Two recent important studies ${ }^{[14]}$ in Enochic traditions trace the origin of the image of Enoch as a primeval sage preoccupied with divine secrets to some heroes of the Mesopotamian lore.

According to these studies, one of these possible prototypes can be an intriguing character of the "Sumerian" Kings list--Enmeduranki, king of Sippar. In three copies of the List he occupies the seventh place, which in Genesis' genealogy belongs to Enoch. In other Mesopotamian sources Enmeduranki appears in many roles and situations remarkably similar to Enoch's story. One of these roles is that of the knower and the guardian of the secrets of gods. ${ }^{[15]}$

The tablet from Nineveh, possibly dated before 1100 B.C.E., is a primary witness to the parallels between the stories of Enoch and Enmeduranki. ${ }^{[16]}$ The text, reconstructed by W.G. Lambert, $\frac{[17]}{11}$ describes Enmeduranki's initiation into the divine secrets and attests him as "the learned savant, 
who guards the secrets of the great gods." In this text ${ }^{[18]}$ Enmeduranki also functions as a mediator between the deities and the people of Nippur, Sippar and Babylon. He instructs them in the secrets, which he received from the deities.

Kvanvig observes that the tablet emphasizes the esoteric character of the divine wisdom revealed to Enmeduranki, reinforced by such terms as nisirtu (mystery) and piristu (secret). ${ }^{[19]}$ Another important detail in the passage is the juxtaposition of the terms "secrets" and "mysteries" with the phrases "heaven and underworld" and "heaven and earth." Kvanvig points out that both phrases have a "cosmological" meaning. ${ }^{[20]}$ Intended to describe the totality of creation--"the whole world," this terminology can also be related to cosmogonic and creational concepts.

\section{Secrets in Enochic traditions}

Just as the role of Enoch as the Knower of secrets does not begin in 2 Enoch, so the information about the heavenly secrets is also not pecular only to this apocalypse. We encounter this theme in other Biblical and the Pseudepigraphical texts, ${ }^{[21]}$ including the early Enochic booklets of 1 Ethiopic Enoch.

1 Enoch applies the term "secrets" to various things Enoch acquires during his celestial tour. In 41:1-3 Enoch tells about his experience:

...I saw all the secrets of heaven, and how the kingdom is divided, and how the deeds of men are weighed in the balance. There I saw the dwelling of the chosen and the resting-places of the holy; and my eyes saw there all the sinners who deny the name of the Lord of Spirits being driven from there, and they dragged them off, and they were not able to remain because of the punishment which went out from the Lord of Spirits. And there my eyes saw the secrets of the flashes of lightning and the thunder, and the secrets of the winds, how they are distributed in order to blow over the earth, and the secrets of the clouds and of the dew.... ${ }^{[22]}$

The passage shows that in 1 Enoch the secrets include not only astronomical, cosmological, and calendar information, but also eschatological details which Enoch acquired either himself or through angelic mediators. ${ }^{[23]}$ The unity between the cosmological and the eschatological, between the secrets of "heaven" and the secrets of "earth," is prominent in 1 Enoch 52:2, where Enoch attests that he "saw the secrets of heaven, everything that will occur on earth: a mountain of iron, and a mountain of copper, and a mountain of silver, and a mountain of gold, and a mountain of soft metal, and a mountain of lead... all these things which serve the authority of the Messiah." ${ }^{[24]}$ M. Bockmuehl notes that cosmological and eschatological secrets occur repeatedly in tandem and show the intimate link between the cosmological mysteries of heaven and the eschatological questions pursued by the visionaries. ${ }^{[25]}$

The tendency to include the knowledge about future eschatological events in the notion of "secrets" can be found both in the Pseudepigrapha and in the Bible. M. Bockmuehl observes that the term zr in Daniel always relates in some way to a disclosure of the future. ${ }^{[26]}$ The labeling of disclosures of the future as "secrets" becomes a prominent motif in the later "Enochic" text, Sefer Hekhaloth. In 3 Enoch 11:2-3 Enoch-Metatron tells R. Ishmael that from the time of his elevation he has acquired an ability to see deep secrets and wonderful mysteries. ${ }^{[27]}$ According to the text, before a man thinks in secret, Metatron is able see his thought; before a man acts, he can see his act. Metatron concludes that "there is nothing in heaven above or deep within the earth concealed from me." $[28]$ It is clear that the passage understands "secrets" to be foresights of 
human deeds and thoughts.

3 Enoch also demonstrates some other affinities with 1 Enoch in its usage of the notion "secrets." First, it applies the word "secrets" to various revealed "things"--"all mysteries of wisdom, all the depths of the perfect Torah, and the thoughts of human hearts." $\stackrel{29]}{ }$ Second, in similarity with 1 Enoch, it includes eschatological and historical details into the category of the "secrets". Third, the angels in 3 Enoch are aware of God's secrets: "YHWH the God of Israel is my witness that when I revealed this secret to Moses, all the armies of the height, in every heaven, were angry with me...."[30] Fourth, Gruenwald's research emphasizes the close proximity between apocalyptic and Merkabah mysticism in the concept of "secret oath/name" which plays a significant role in the cosmology of 1 Enoch and 3 Enoch. ${ }^{[31]}$

In contrast to these apocalyptic and Merkabah Enochic texts, 2 Enoch offers a different understanding of "secrets." At least four points of difference need to be noted. First, 2 Enoch does not apply the notion of "secrets" to many types of revelation. This term, occurs very rarely in the book and is reserved only for the particular cosmogonic ${ }^{[32]}$ revelation of the Lord. Second, the term is never applied to an earthly affair, not even in reference to historical and eschatological information. Third, the "secret name" does not play any significant role in 2 Enoch's cosmogony. Fourth, the angels in 2 Enoch do not know about God's cosmogonic "secrets."

Moreover, it seems that in 2 Enoch the realm of the secrets, even "topologically," transcends the angelic world. The shorter recension tells that before the cosmogonic revelation took place, the Lord had "placed" Enoch to the left of Himself, closer than Gabriel. ${ }^{[33]}$ Further, the Lord confirms the transcendence of the knowledge about creation over the angelic world when He informs Enoch that even to his angels He has explained neither his secrets nor his "endless and inconceivable creation which He conceived." [34]

The "secrecy" of the Lord's revelation is underscored further by several additional factors. First, immediately following the cosmogonic instructions, the Lord informed Enoch that he appointed an intercessor, the archangel Michael, and guardian angels, Arioch and Marioch, ${ }^{[35]}$ for Enoch's writings which should not perish in the impending flood:

For I will give you an intercessor, Enoch, my archistratig, Michael, on account of your handwritings and the handwritings of your fathers - Adam and Seth. They will not be destroyed until the final age. For I have commanded my angels Arioch and Marioch, whom I have appointed on the earth to guard them and to command the things of time to preserve the handwritings of your fathers so that they might not perish in the impending flood which I will create in your generation $(33: 10-12)$.

The motif of the guardian angels of the books is pecular to the esoteric tradition conveyed to Enoch. It might indicate that we deal here with the famous "secret" books by which antediluvian wisdom reached postdeluvian generations. This motif of antediluvian "secret" writings has a number of parallels in Mesopotamian lore. ${ }^{[37]}$

Second, the esoteric details of the Lord's cosmogonic revelations do not appear in chapters 3966, dedicated to Enoch's instructions to his children. In these chapters Enoch shares the information about his heavenly tour and his extraordinary experiences near the Throne of Glory. He conveys to his children an esoteric knowledge which includes meteorological, cosmological and eschatological information. In this section of the book Enoch even offers a lengthy description of the Lord's limbs "without measure and analogy" $[38]$ which, some scholars believe, belongs to another highly esoteric trend of Jewish mysticism. $\stackrel{[39]}{ }$ The full account of God's 
cosmogonic revelations, however, does not appear in these instructions of Enoch. Even though the text makes several allusions to the creation story, telling that "the Lord was the one who laid the foundations upon the unknown things and... spread out the heavens above the visible and the invisible things, $[40]$ Enoch never discloses to his children the full story about Adoil and Aruchas.

\section{Secrets of Creation in Merkabah Tradition}

Despite the differences in the treatment of "secrets" in 2 Enoch and 3 Enoch that have been mentioned earlier, the approach to the mysteries of creation found in 3 Enoch demonstrates close affinities with the Slavonic Enoch.

The theme of the secrets of creation plays an important role in 3 Enoch; it is surrounded by several details found in 2 Enoch. The similarities include the following points:

1. One of these parallels is Enoch's initiation into the secrets of Creation. The important detail in both texts is that some preparatory instructions before the account of creation were given through angels. In the case of 3 Enoch, the instructions were given through the angels known as the "Prince of Wisdom" (hmkxh r\#) and the "Prince of Understanding" (hnybh r\#); in the case of 2 Enoch they came through the angel Vereveil (?e?e?e??). In both books these angelic mediators do not reveal "secrets" but offer instead some preparatory knowledge. In 2 Enoch Vereveil instructs Enoch in different "things"--"all things of heaven and earth and sea and all the elements and the movements and their courses... and the Hebrew language, every kind of language of the new song of the armed troops and everything that it is appropriate to learn" (23:1-2)." Enoch the Prince of Wisdom and the Prince of Understanding teach Enoch-Metatron "wisdom"-"the wisdom of those above and those below, the wisdom of this world and the world to come." $[42]$

2. Both texts also mention that immediately after these preparatory angelic instructions, the Lord (the Holy One) reveals "the secrets of creation" to Enoch (Metatron). From 3 Enoch 11:2 we learn that all the secrets of creation (yrts ty\#)rb) ${ }^{[43]}$ now stand revealed before Enoch-Metatron as they stand revealed before the Creator. In 2 Enoch 24:2-4 the Lord instructs Enoch in the secrets of his "endless and inconceivable creation," the mysteries which he never explained even to his angels:

Whatever you see, Enoch, things standing still and moving about and which were brought to perfection by me, I myself will explain it to you... And not even to my angels have I explained my secrets, nor related to them their composition, nor my endless and inconceivable creation which I conceived, as I am making them known to you today.

3. As was mentioned earlier, the notion of "secrets" in 3 Enoch includes various types of revelations. Even though the book applies the term "secrets" to several things, including the Torah, it also seems to use the notion of "the special secret" in reference to certain details of the Account of Creation. According to the book, this special secret plays an important role in "God's creation of everything." We learn about the secret from 3 Enoch 48D, where Metatron tells to R. Ishmael that he was the person who revealed the special secret to Moses, in spite of the protests of the heavenly hosts:

YHWH the God of Israel is my witness that when I revealed this secret to Moses, all the armies 
of the height, in every heaven, were angry with me. They said to me, "Why are you revealing this secret to humankind, born of woman, blemished, unclean, defiled by blood and impure flux, men who excrete putrid drops--that secret by which heaven and earth were created, the sea and the dry land, mountains and hills, rivers and springs, Gehinnom, fire and hail, the garden of Eden and the tree of life? By it Adam was formed, the cattle and the beasts of the field, the birds of heaven and the fish of the sea, Behemoth and Leviathan, the unclean creatures and reptiles, the creeping things of the sea and the reptiles of the deserts, Torah, wisdom, knowledge, thought, the understanding of things above, and the fear of heaven. Why are you revealing it to flesh and blood?"[45]

P. Alexander observes that in this passage "the secret" could be either (1) the Torah, or (2) the secret names of God. He further suggests that "the identification of the secret with the Torah appears to be excluded by the fact that Torah is one of the things created by the secret." ${ }^{[46]}$ This situation in which the notion of "secret" transcends the realm of the Torah and refers instead to God's creation appears to have close affinities to the position of 2 Enoch, where the Torah is not listed among God's mysteries.

\section{Secrets of Creation in Zoharic Tradition}

The cosmogonic account in 2 Enoch demonstrates close similarities not only with the Merkabah tradition but also with much later developments of Jewish mysticism. The following analysis is an attempt to trace some affinities between the account of creation in 2 Enoch and in some medieval texts of Jewish mysticism.

\section{Stones}

In one of his books ${ }^{[47]} \mathrm{G}$. Scholem points to an interesting detail of the creation narrative in 2 Enoch. The story involves the enigmatic stones the Lord placed in the waters during the process of creation. In chapters 28-29, when the Lord instructed Enoch about the secrets of the Account of Creation, He said:

Then from the waters I hardened ${ }^{[48]}$ big stones, ${ }^{[49]}$ and the clouds of the depths ${ }^{[50]}$ I commanded to dry themselves. And I did not name what fell to the lowest places. ${ }^{[51]}$ Gathering the ocean into one place, I bound it with a yoke. I gave to the sea an eternal boundary, which will not be broken through by the waters. The solid structure ${ }^{[52]}$ I fixed and established it above the waters (28:24). $[53]$

The theme of the "big stones" plays an important role in the creation narrative of 2 Enoch. G. Scholem draws attention to the relationship between these enigmatic stones and the cosmogonic tradition of "an esoteric baraitha ${ }^{[54]}$ in which the word whb in whbw wht of Genesis 1:2 was interpreted as 'muddy stones, sunk in the abyss'." ${ }^{[55]}$ Scholem's remark ${ }^{[56]}$ invites a further exploration into the role of the enigmatic stones in Aggadic traditions. Hag. 11b prohibits the exposition of ty\#)rb $\mathrm{h \# (} \mathrm{m}$ in the public. Cosmogonic doctrines, however, were important during all stages of Jewish mysticism, $\stackrel{[57]}{ }$ and occupied a prominent role in such books as Sefer Yetsirah and Sefer Bahir. ${ }^{[58]}$ Isaiah Tishby observes that the understanding of the causes and processes of the formation of the world became one of the central themes in late Jewish mysticism. ${ }^{[59]}$ In late Jewish mysticism, especially in the Zohar, the theme of the big stones placed by the Creator in the waters (in the abyss) occupied an important place. In spite of the late date of the 
Zohar, these materials have preserved important early traditions relevant to the subject of our research. Moreover, this medieval compendium of Jewish mystical knowledge mentions a book under the title "The Book of the Secrets of Enoch" $[60]$ which is identical with the titles given to 2 Enoch in some manuscripts. $\stackrel{\text { [61] }}{6}$ Similarities between 2 Enoch and the Zohar are not confined only to the title of the Slavonic Enoch. Several scholars, including G.H. Box and H. Odeberg, have noted striking parallels between both texts, especially in the materials of the longer recension. G. H. Box points to the connection between 2 Enoch and the Zohar and observes that "the Slavonic Enoch ... is remarkably illuminating in its realistic presentment of some of the Kabbalistic ideas--e.g. as to the process of creation, the constitution of the heavens, and so on." $[62] \mathrm{H}$. Odeberg, who was Box's student at the University of London, holds a similar view. ${ }^{[63]}$ In spite of some apparent deficiencies in his edition ${ }^{[64]}$ of 3 Enoch his work contains important insights into possible relationships between the Slavonic Enoch and late Jewish mysticism. Odeberg, who used Forbes' separate translations of the shorter and longer recensions of 2 Enoch, makes a number of provocative comments on the nature of the Jewish mystical traditions incorporated in these texts. In his opinion, the longer recension sometimes contains concepts that belong to a later (postHekhaloth) development of Jewish mysticism. In this respect, he found a number of striking similarities with Zoharic tradition. It should be noted that Odeberg's position was partially conditioned by his favoring of the shorter recension as more ancient and original. ${ }^{[65]} \mathrm{He}$ viewed the longer recension as a later expansion of the shorter one. In the light of the recent studies of F. Andersen, J. Charlesworth, ${ }^{[66]}$ A. de Santos Otero, ${ }^{[67]}$ and C. Böttrich, ${ }^{[68]}$ who argue for the originality of the longer recension, Odeberg's hypothesis is losing its persuasive power. In this context, an investigation of the possible parallels between the story of creation in 2 Enoch and the Account of Creation in the Zohar can contribute not only to our understanding of the hypothetical provenance of the longer recension but to the provenance of the text in general. It also can clarify the formative value of the account of creation in 2 Enoch for subsequent rabbinic developments. The importance of such inquiry constitutes one of the reasons for the inclusion of some materials from the Book of Zohar in our research.

Zohar I, 231a reads:

The world did not come into being until God took a certain stone, which is called the "foundation stone," $[69]$ and cast it into the abyss ${ }^{[70]}$ so that it held fast there, and from it the world was planted. This is the central point of the universe, and on this point stands the holy of holies. This is the stone referred to in the verses, "Who laid the corner-stone thereof" (Job XXXVIII, 6), "the stone of testing, the precious corner-stone" (Is. XXVIII, 16), and "the stone that the builders despise became the head of the corner" (Ps. CXVIII, 22). This stone is compounded of fire, water, and air, and rests on the abyss. Sometimes water flows from it and fills the deep. This stone is set as a sign in the centre of the world. ${ }^{[71]}$

Zohar II, 222a continues the theme of the foundation stone:

When the Holy One, blessed be He, was about to create the world, He detached one precious stone ${ }^{[72]}$ from underneath His Throne of Glory and plunged it into the Abyss, one end of it remaining fastened therein whilst the other end stood out above; and this other and superior head constituted the nucleus of the world, the point out of which the world started, spreading itself to right and left and into all directions, and by which it is sustained. That nucleus, that stone, is called shethyiah (foundation), as it was the starting-point of the world. The name shethyiah, furthermore, is a compound of shath (founded) and Yah (God), signifying that the Holy One, 
blessed be He, made it the foundation and starting-point of the world and all that is therein. ${ }^{[73]}$ We will now examine some important details in these two narratives. The text of 2 Enoch uses the term ße? $\mathrm{d}^{\mathrm{[}} \mathrm{a}^{74]}$ (literally, "abyss") which also occupied a prominent place in the narrative of the Zohar. In the Zohar, the Holy One cast a stone into the abyss. 2 Enoch does not mention that the stone fell into the abyss but does utilize the phrase, "I did not name what fell to the abyss" (28:3), with the implication that this act of the Lord had already taken place.

Another important motif in relation to the stones in both texts has to do with the theme of "establishing the foundation." 2 Enoch tells that the stones (stone) are related to the foundation which the Lord has established above the waters. ${ }^{[75]}$ This labeling of stones as "foundation" is very typical for the Zoharic narrative, where the stone is referred to many times as hyt\# ("foundation") or hyt\# $\mathrm{Nb}$ ) ("foundation stone"). The concept of the "Foundation Stone" occupies a prominent place in several cosmological stories. ${ }^{[76]}$ E. Burrows' research points to the Mesopotamian provenance of the concept of the "Foundation Stone," which symbolises in these traditions the bond between heaven and earth. ${ }^{[7]}$ Burrows traces the geographical origins of this cosmogonic pattern to "the sanctuaries at Nippur, at Larsa, and probably at Sippar." ${ }^{\text {[78] }}$ The possible connection with Sippar is especially important for the Enochic text, if we keep in mind the possible Mesopotamian origin of Enoch's figure, based on the antediluvian king Enmeduranki of Sippar.

Finally, the difference in the number of stones in both texts must also be explained. The Zohar tells about one foundation stone, 2 Enoch speaks about stones. ${ }^{[79]}$ But later in the narrative of 2 Enoch, the term switches from the plural to the singular, and refers only to one stone: "From the stone ${ }^{[80]}$ I cut off a great fire...(29:3)."[81]

\section{Adoil and Arukhaz: Etymology of the Names}

During His instructions in the secrets of creation, the Lord told Enoch that in the beginning of creation He had thought to create a visible creation from the invisible. This process occupies an important place in the narrative of 2 Enoch and demonstrates a complicated imagery of this stage of creation. To assist our inquiry, the following passage must be quoted:

The Lord told Enoch: And I thought up the idea of establishing a foundation, to create a visible creation. And I commanded the lowest things: "Let one of the invisible things come out visibly!" And Adoil ${ }^{[82]}$ descended, extremely large. And I looked at him, and, behold, in his belly he had a great age. ${ }^{[83]}$ And I said to him, "Disintegrate yourself, Adoil, and let what is disintegrated from you become visible." And he disintegrated himself, and there came out from him the great age. And thus it carried all the creation which I had wished to create. And I saw how good it was. And I placed for myself a throne, and I sat down on it. To the light I spoke: "You go up higher and be solidified and become the foundation for the highest things." And there is nothing higher than the light, except nothing itself. And I spoke, I straightened myself upward from my throne. And I called out a second time into the lowest things, and I said, "Let one of the invisible things come out solid and visible." There came out Arukhas ${ }^{[84]}$, solid and heavy and very black. And I saw how suitable he was. And I said to him, "Come down low and become solid! And become the foundation of the lowest things!" And there is nothing lower than the darkness, except nothing itself (24-25-26). $\stackrel{[85]}{ }$

The passage deals with two enigmatic names, Adoil and Arukhas. Much attention has been devoted to the etymology of these words which might indicate that many scholars consider these names as important cues for clarifying the origins of the text. 
R.H. Charles asserts that Adoil might be derived from Hebrew, 1) dy, translated as "The hand of God." ${ }^{[86]}$ M. Philonenko supports this etymology pointing to some Egyptian parallels in which "les premières créatures naissent du liquide séminal que le démiurge solitaire avait fait jaillir au moyen de sa main."

L. Cry suggests reading Adoil as 1) rw), "the light of God". In his opinion, some letters in the Hebrew word rw), "light," were transformed. Resh was changed into daleth. Waw was transposed. As a result of these transformations, it sounds like Adoil. ${ }^{[88]}$

A. Vaillant suggests that the name might be derived from a Hebrew word d( with a suffix, "his eternity, his aeon." ${ }^{89]}$ G. Scholem criticizes this rendering and shows that in Hebrew the word d( has the peculiar characteristic of being unable to carry a pronominal suffix. ${ }^{[90]}$ According to Scholem's own interpretation Adoil derives from Sadoqil.

J. Milik considers the name Adoil as "a Greek and Semitic hybrid: Hades + El." ${ }^{[92]}$ G. Quispel derives it from Adonai-el, where the first element is the circumlocution for the Tetragrammaton. ${ }^{[93]}$

Another proper name in the narrative, Arukhaz, also poses several problems for interpretation.

R.H. Charles believes that Arukhaz may have originated from the Hebrew word (yqr ("firmament"). [94]

A. Vaillant supports the view that the term "Arukhaz" is connected with the image of foundation (Greek, stere\&wma; Hebrew, (yqr). In his opinion it was composed from the Hebrew words Kwr( "arranged" and z( "hard."[95]

J. Milik traced "Arukhaz" to the Hebrew feminine term hkwr) ("geographical basin"), transcribed with the masculine flexional ending as Aruchaz. ${ }^{[96]}$

F. Andersen, while thinking that the name could probably be derived from the Greek word a0rxh\&, points out that the ending -as, which is not Slavonic, is doubtful. ${ }^{[97]}$ He opts for another translation that connects the name with a Hebrew word Kwr( ("extended"). ${ }^{[98]}$

However, some materials found in the Zohar might lead us to quite different interpretations of the names "Adoil" and "Arukhas." In the Zohar I, 17b one may find some provocative material from the Account of Creation that describes the same stage in the story of creation which began, just as the passage of 2 Enoch, with the idea of establishing a "foundation:"

Let there be a firmament: i.e. let there be a gradual extension. Thereupon $E l$ (God), the "right cluster," El Gadol (Great God), ${ }^{[99]}$ spread forth from the midst of the waters to complete this name $E l$ and to combine with this extension, and so $E l$ was extended into Elohim $(=E l+H, Y, M)$. These $H, Y, M$, extended and became reversed so as to form lower waters, $Y, M, H$. This extension which took place on the second day is the upper waters. The hé, yod, mim, form hayat (the sea), which the upper waters. The reversal of these letters, yamah (seaward), is the lower waters. When they were firmly established, all became one whole, and this name was extended to a number of places. The upper waters are male and the lower waters female. At first they were commingled, ${ }^{[100]}$ but afterwards they were differentiated into upper and lower waters. This is the meaning of "Elohim upper waters," and this is the meaning of "Adonai lower waters;" and this is the meaning of upper Hé and lower Hé. ${ }^{\text {101] }}$

First, the applicable correlation between this narrative and the passage of 2 Enoch lies in the similarities between the name "Adail" which is spelled in the majority of Slavonic manuscripts as "Adoil" 102$]$ and lwdg 1) - El gadol (or Gadol-el, "the great one"). Let it be noted that the Slavonic text, after it introduces the name "Adoil," defines it as "the great one": ?d??? | p?e?e???? 7$\} ? ?^{[103]}$ "Adoil, the great one," ${ }^{[104]}$ which, in Hebrew, is identical with his name. [105] Second, the title $\mathrm{El} \mathrm{Gadol}$ in the Zohar is identified with the upper waters. A similar 
correspondence can be found in 2 Enoch where Adoil is matched with the upper foundation. The same symmetrical pattern also shows in the case of Arukhaz: Arukhaz, the lower foundation in 2 Enoch, and the "other extension," the lower waters in the Zohar. Both texts use the term "lower" in reference to Arukhaz. This term can serve as a clue to resolving the etymological mystery of this enigmatic name. The word "Arukhaz" in 2 Enoch might be related to the Aramaic yy(r), translated as "lower." ${ }^{[106]}$ Noteworthy, that Frg.Tg. on Gen 1:6 uses this term in the expression "the lower waters" (y)(r) )ym). $\stackrel{[107]}{ }$

\section{Conclusion}

It would be helpful now to offer some concluding remarks about the Account of Creation in 2 Enoch. These inferences will be concerned mainly with the form and the content of the examined textual material.

1. 2 Enoch appears to contain a systematic tendency of treating the story of creation as the most esoteric knowledge. Even though 2 Enoch deals with various meterological, astronomical, and cosmological revelations, it specifically emphasizes the "secrecy" of the account of creation. 2 Enoch, unlike other early apocalyptic materials (such as the Book of Daniel and 1 Enoch), does not include the variety of "revealed things" in the notion of "secrets."

2. 2 Enoch's emphasis on the "secrecy" of the creation story demonstrates an intriguing parallel to the later rabbinic approach to ty\#)rb h\#(m as an esoteric knowledge. 2 Enoch, therefore, can be seen as an important step in the shaping of the later Rabbinic understanding of "secret things," which eventually led to the esoterism of the Account of Creation.

3. The Account of Creation in 2 Enoch includes the cosmogonic motifs of God's creation of the primordial order. These descriptions show a number of parallels with late Jewish mysticism, namely the Zoharic tradition. It supports the Box-Odeberg hypothesis, that the creation narrative of the longer recension shows a presentiment of some of the Zoharic ideas about the process of creation. At this stage of our research, it is difficult to determine whether these blocks of the Account of Creation are interpolations during the later stages of transmission or whether they belong to the original layer of the text.

4. The story of Creation appears to be more developed in the manuscripts of the longer recension. To illustrate this fact, we could point to the important description of the creation of Adam ${ }^{[108]}$ in chapters 30-32, which are absent in the manuscripts of the shorter recension. It supports Andersen's position that "the claims of the longer recension need special attention in the sections dealing with creation, chapters 24-33."[109]

11 Several MSS do not include the word "secrets" in their titles. Among them - $J$ ("The word of Enoch..."), B ("The life of righteous Enoch..."), $\operatorname{MPr}$ ("From the book of righteous Enoch"), $P^{2}$ ("The book of Enoch the son of Ared"). Cf. M.I. Sokolov, "Materialy i zametki po starinnoj slavjanskoj literature. Vypusk tretij, VII. Slavjanskaja Kniga Enoha Pravednogo. Teksty, latinskij perevod i izsledovanie. Posmertnyj trud avtora prigotovil k izdaniju M. Speranskij," COIDR 4 (1910) 2.47; 2.83; 2.106 and 1.145.

[2] ta???. Cf. A. Vaillant, Le livre des secrets d'Henoch: Texte slave et traduction française (Paris: Institut D'Etudes Slaves, 1952) 2. 
${ }^{[3]}$ Cf. MSS A: "From the secret book(s) about the taking away of Enoch the just," Tr.: "Which are called the secret books of Enoch," $U$ : "From the secret books about the taking away of Enoch the just," and Rum.: "From the secret books of Enoch." Cf. F. Andersen, "2 (Slavonic Apocalypse of) Enoch," The Old Testament Pseudepigrapha (ed. J.H. Charlesworth; New York: Doubleday, 1985 [1983]) 1.103; Sokolov, 1.161; 1.111; and 1.153.

${ }^{[4]}$ MSS $V, N$ "And these are the books (called) the secrets of God, a revelation to Enoch." Sokolov, 1.83. Cf. also $B^{2}$ "This is the book of the secrets of God, a revelation to Enoch." Sokolov, 1.133.

${ }^{[5]}$ Cf. $P$ "The book (about) the secrets of Enoch, the son of Ared," and $R$ "The books of the holy secrets of Enoch..." Cf. A. Vaillant, Le livre des secrets d'Henoch: Texte slave et traduction française (Paris: Institut D'Etudes Slaves, 1952) 1 and Sokolov, 1.1.

[6] Andersen, 140.

[7] Andersen, 144.

${ }^{[8]}$ Andersen, 140.

[9] ta??? $\mu$ ?. Vaillant, 36.

[10] Andersen, 161

[11] The origin of the role in Enochic traditions can be traced to 1 Enoch 72:1; 74:2; and 80:1. In 1 Enoch 41:1 Enoch is attested as the one who "saw all secrets of heaven..." M. Knibb, The Ethiopic Book of Enoch (2 vols; Oxford: Clarendon Press, 1978) 2.128.

[12] 3 Enoch 11:2. Here and later I have used Philip Alexander's English translation of 3 Enoch, and follow his division in chapters. Cf. P. Alexander "3 (Hebrew Apocalypse of) Enoch," The Old Testament Pseudepigrapha (ed. J.H. Charlesworth; New York: Doubleday, 1985 [1983]) 1.264.

${ }^{[13]}$ H.S. Kvanvig, Roots of Apocalyptic: the Mesopotamian Background of the Enoch Figure and of the Son of Man (WMANT, 61; Neukirchen-Vluyn: Neukirchener Verlag, 1988) 27.

[14] J. VanderKam, Enoch and the Growth of an Apocalyptic Tradition (The Catholic Biblical Quarterly Monograph Series, 16; Washington: The Catholic Biblical Association of America, 1984); H.S. Kvanvig, Roots of Apocalyptic: the Mesopotamian Background of the Enoch Figure and of the Son of Man (WMANT, 61; Neukirchen-Vluyn: Neukirchener Verlag, 1988). On Mesopotamian origins of Enoch's figure cf. also: H. Zimmern, "Urkönige und Uroffenbarung" in E. Schrader, Die Keilinschriften und das Alte Testament (2 vols.; Berlin: Reuther\& Reichard, 1902-3) 2.530-43; H. L. Jansen, Die Henochgestalt: Eine vergleichende religionsgeschichtliche Untersuchung (Norske Videnskaps-Akademi i Oslo II. Hist.-Filos. Klasse, 1; Oslo: Dybwad, 1939); P. Grelot, "La Légende d'Hénoch dans les apocryphes et dans la Bible: son origine et signification" RSR 46 (1958) 5-26, 181-210.

${ }^{[15]}$ P. Grelot, "La légende d'Hénoch dans les apocryphes et dans la Bible: origine et signification", RSR 46 (1958) 182 and 186. Enmeduranki was also regarded as the founder of the ba2ru3 guild, the elite group of diviners, the experts in omens. Cf. J. VanderKam, Enoch and the Growth of an Apocalyptic Tradition (The Catholic Biblical Quarterly Monograph Series, 16;

Washington: The Catholic Biblical Association of America, 1984) 42.

[16] Kvanvig, 190.

[17] W.G. Lambert, "Enmeduranki and Related Matters," JCS 21 (1967) 126-38.

[18] The text reads as follows:

3. Shamash in Ebabbara [appointed]

1. Enmeduranki [king of Sippar],

2. the beloved of Anu, Enlil [and Ea]. 
4. Shamash and Adad [brought him in] to their assembly,

5. Shamash and Adad [honored him],

6. Shamash and Adad [set him] on a large throne of gold,

7. They showed him how to observe oil on water, a mystery of Anu, [Enlil and Ea],

8. They gave him the tablet of the gods, the liver, a secret of heaven and [underworld],

9. They put in his hand the cedar[-rod], beloved of the great gods.

10. Then he, in accordance with their [word(?)] brought

11. the men of Nippur, Sippar and Babylon into his presence,

12. and he honoured them. He set them on thrones before [him],

13. he showed them how to observe oil on water, a mystery of Anu, Enlil and Ea,

14. He gave them the tablet of the gods, the liver, a secret of heaven and underworld,

15. He put in their hand the cedar[-rod], beloved of the great gods.

16. \{ The tablet of the gods, the liver, a mystery of heaven and underworld;

17. how to observe oil on water, a secret of Anu, Enlil and Ea;

18. 'that with commentary,' When Anu, Enlil; and how to make mathematical calculations.\}

19. The learned savant, who guards the secrets of the great gods,

20. will bind his son whom he loves with an oath

21. before Shamash and Adad by tablet and stylus and

22. will instruct him. When a diviner,

23. an expert in oil, of abiding descent, offspring of Enmeduranki, king of Sippar,

24. who set up the pure bowl and held the cedar[-rod],

25. a benediction priest of the king, a long-haired priest of Shamash

26. as fashioned by Ninhursagga,

27. begotten by a nisakku-priest of pure descent:

28. if he is without blemish in body and limbs

29. he may approach the presence of Shamash and Adad where liver inspection and oracle (take place)." W.G. Lambert, "Enmeduranki and Related Matters," 132.

${ }^{[19]}$ Kvanvig, 188.

[20] Kvanvig, 188.

$[21]$ On the notion of "secrets" in the Old Testament and the Pseudepigrapha cf. Markus N.A.

Bockmuehl, Revelation and Mystery in Ancient Judaism and Pauline Christianity (WUNT, 2. Reihe, 136; Tübingen: Mohr/Siebeck, 1990). Qumran texts also use extensively the notions of "secret" (zr) and "special knowledge" (t(d) and apply them to varied things, including the Torah and the halachic preceipts. Cf. Markus N.A. Bockmuehl, Revelation and Mystery in Ancient Judaism and Pauline Christianity, 53-6; W.D. Davies, "'Knowledge' in the Dead Sea Scrolls and Matthew 1.1:25-30" in Davies, Christian Origins and Judaism (London, 1962) 119-144; B. Reicke, "Da ${ }^{c}$ at and Gnosis in Intertestamental Literature," Neotestamentica et Semitica. Studies in Honor of Matthew Black (eds. E. Earle Ellis and Max Wilcox; Edinburg: Clark, 1969) 245-55; H. Ringgren, "Qumran and Gnosticism," Le Origini dello Gnosticismo (ed. U. Bianchi; Leiden: Brill, 1967) 379-88.

${ }^{[22]}$ Knibb, 2.128-9.

${ }^{[23]}$ For the complete discussion about "revealed things" in apocalyptic literature see M. Stone's pioneering research in M. Stone "Lists of Revealed Things in the Apocalyptic Literature," Magnalia Dei: The Mighty Acts of God ( eds. F.M. Cross, W.E. Lemke, and P.D. Miller, Jr.; New York: Doubleday, 1967) 414-52.

${ }^{[24]} \mathrm{Knibb}, 2.136$. 
${ }^{[25]}$ Markus N.A. Bockmuehl, Revelation and Mystery in Ancient Judaism and Pauline Christianity (WUNT, 2. Reihe, 136; Tübingen: Mohr/Siebeck, 1990) 35.

${ }^{[26]}$ Markus N.A. Bockmuehl, Revelation and Mystery in Ancient Judaism and Pauline Christianity (WUNT, 2. Reihe, 136; Tübingen: Mohr/Siebeck, 1990) 36.

${ }^{[27]}$ h)lpwm dwsbw hqwm( yzrb lktshl. Cf. P. Schäfer with M. Schlüter and H.G. von Mutius, Synopse zur Hekhaloth-Literatur (TSAJ, 2; Tübingen: Mohr/Siebeck, 1981) 9.

[28] Alexander, 1.264.

[29] 3 Enoch 11:1. Cf. Alexander, 1.264.

[30] Alexander, 1.315.

[31] I. Gruenwald, Apocalyptic and Merkavah Mysticism (AGJU, 14; Leiden: Brill, 1980) 10-11.

${ }^{[32]}$ On cosmogony in 2 Enoch cf.: S. Pines, "Eschatology and the Concept of Time in the Slavonic Book of Enoch," in Types of Redemption (ed. R.J. Zwi Werblowsky; Leiden: E.J. Brill, 1970) 72-87; M. Philonenko, "La cosmogonie du 'Livre des secrets d'Hénoch,"' Religions en Egypte: Hellénistique et Romaine (Paris: Presses Universitaires de France, 1969) 109-16; G. Scholem, On the Mystical Shape of the Godhead (New York: Schocken, 1991) 98-101; idem, Origins of the Kabbalah (Princeton: Princeton University Press, 1987).

[33] Andersen, 143.

[34] Andersen, 143.

[35] On the origin of the names Arioch and Marioch see J. Fossum, The Name of God and the Angel of the Lord, 321-8; L. Cry, "Quelques noms d'anges ou d'êtres mysterieux en II Henoch," RB 49 (1940) 199-200.

[36] Andersen, 157.

${ }^{[37]}$ Cf. P. Grelot, "La légende d'Hénoch dans les apocryphes et dans la Bible: origine et signification", RSR 46 (1958) 9-13.

[38] Andersen, 163.

[39] G. Scholem argues that the terminology of this section in 2 Enoch shows apparent similarities to hmwq rw(y\# tradition. Cf. G. Scholem, On the Mystical Shape of the Godhead (New York:

Schocken, 1991) 29.

[40] Andersen, 174.

[411 Andersen, 140.

[42] Alexander, 264.

${ }^{[43]}$ MS M40. Cf. P. Schäfer with M. Schlüter and H.G. von Mutius., Synopse zur HekhalothLiteratur (TSAJ, 2; Tübingen: Mohr/Siebeck, 1981) 8. MS V228 instead of "the secrets of creation" uses - "the orders of creation" (ty\#)rb yrds). Cf. P. Schäfer with M. Schlüter and H.G. von Mutius., Synopse zur Hekhaloth-Literatur (TSAJ, 2; Tübingen: Mohr/Siebeck, 1981) 9.

[44] Andersen, 143.

[45] Alexander, 315.

[46] Alexander, 315.

[47] G. Scholem, Origins of the Kabbalah (Princeton: Princeton University Press, 1987), 73.

[48] The verb ?t? ??d?t? could be also rendered as "to place." Sreznevskij's dictionary lists this translation among possible meanings of the Slavonic word. See I. Sreznevskij, Slovar' drevnerusskogo yazyka (3 vols.; Moscow: Kniga, 1989) III(II), 1306.

[49] ?aue??e ?e????. Vaillant, 30.

${ }^{[50]}$ Be?d?? $\mu$ |. Vaillant, 30. Another choice for translation can be "abyss." Kurz and Sreznevskij equate the Slavonic term with the Greek albussoj. Cf. J. Kurz, ed., Slovník Jazyka Staroslovenského [Lexicon Linguae Palaeo-Slovenicae] (4 vols.; Prague: Akademia, 1966-) 
1.76; Sreznevskij, Slovar', I(I), 55.

[51] Be?d??. Again the same term, which can be translated as "abyss."

[52] ??e?d) Vaillant, 30. This Slavonic word can be also translated as "a foundation." The previous verb 8 s???a? ("established") favors such a translation.

[53] Andersen, 147.

[54] Hag. 12a.

[55] Scholem, Origins of the Kabbalah, 74. He points also to "the muddy stones from which darkness flows" in the Targum on Job 28:8. Another interesting early parallel could be "stones of bohu" in Isa 34:11.

[56] Gershom Scholem was a unique exception in his field, as he persistently tried to investigate the relationships between 2 Enoch and the Jewish mystical traditions. Even though his observations on possible parallels between 2 Enoch and Jewish texts are not systematic, they are very perceptive and can provide many insights for students of 2 Enoch.

${ }^{[57]}$ Cf. G. Scholem, Major Trends in Jewish Mysticism (New York: Schocken Books, 1954).

${ }^{[58]}$ For the discussion of the parallels between the cosmogonies of these two texts and 2 Enoch cf. G. Scholem, Origins of the Kabbalah, 73-5; idem, On Mystical Shape of the Godhead (N.Y.: Schocken, 1991) 98-100.

[59] I. Tishby, The Wisdom of the Zohar: Anthology of Texts (3 vols.; London: The Littman Library of Jewish Civilization, 1994) 2.549.

[60] Kwnxd Nwzrd )rpsbw. 2.180b. Cf. R. Margaliot, ed., rhzh rps (3 vols.; Jerusalem, 1940) 2.360 .

[611 Cf. $P$ ????a 8 ta??a?| ????????|("The book about the secrets of Enoch") and $R$ ????? s?0t?? ta??) ????? ("The books of the holy secrets of Enoch"). Cf. A. Vaillant, Le livre des secrets d'Henoch: Texte slave et traduction francaise (Paris: Institut D'Etudes Slaves, 1952) 1; Sokolov, 1.1.

${ }^{[62]}$ W.O.E. Oesterley and G.H. Box, A Short Survey of the Literature of Rabbinical and Mediaeval Judaism (New York: Macmillan, 1920) 236.

${ }^{[63]}$ Cf. H. Odeberg, 3 Enoch or the Hebrew Book of Enoch (New York: KTAV, 1973) 1.22.

${ }^{[64]}$ Cf. J. Greenfield, "Prolegomenon," in H. Odeberg, 3 Enoch or the Hebrew Book of Enoch (New York: KTAV, 1973) xi-xlvii.

[65] Although, "original" might be an inappropriate word here. P. Sacchi rightly observes that "the original is an abstract concept; no one possesses the author's manuscript. Even the original of the Book of the Secrets of Enoch is only the most ancient form of the text available, and therefore the closest to the Original (with a capital 'O')." Cf. P. Sacchi, Jewish Apocalyptic and Its History (JSPSS, 20; Sheffield: Sheffield Academic Press, 1990) 237.

${ }^{[66]}$ Cf. J.H. Charlesworth, "The SNTS Pseudepigrapha Seminars at Tübingen and Paris on the Books of Enoch (Seminar Report)," NTS 25 (1979) 315-23; J.H. Charlesworth, The Old Testament Pseudepigrapha and the New Testament. Prolegomena for the Study of Christian Origins (SNTSMS, 54; Cambridge: Cambridge University Press, 1985) 102-06.

[67] A. de Santos Otero, "Libro de los secretos de Henoc (Henoc eslavo)," Apocrifos del AT (ed. A. Dies Macho; Madrid: Ediciones Christiandad, 1984) 4.147-202.

${ }^{[68]}$ C. Böttrich, Weltweisheit, Menschheitsethik, Urkult: Studien zum slavischen Henochbuch (WUNT, R.2, 50; Tübingen: Mohr, 1992); C. Böttrich, Das slavische Henochbuch (Gütersloh: Gütersloher Verlaghaus, 1995); C. Böttrich, Adam als Mikrokosmos: eine Untersuchung zum slavischen Henochbuch (Frankfurt am Main: Lang, 1995).

${ }^{[69]}$ hyt\# Nb). R. Margaliot, ed., rhzh rps (3 vols.; Jerusalem, 1940) 1.461. 
[70] )mwht. R. Margaliot, ed., rhzh rps (3 vols.; Jerusalem, 1940) 1.461.

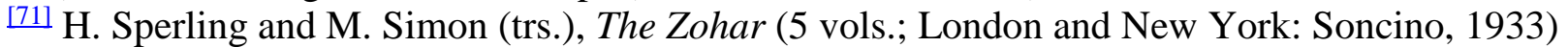
2.399 .

[72] )ryqy )nb). R. Margaliot, ed., rhzh rps (3 vols.; Jerusalem, 1940) 2.443.

${ }^{[73]}$ H. Sperling and M. Simon (trs.), The Zohar (5 vols.; London and New York: Soncino, 1933) 4.258-9.

${ }^{[74]} \mu$ ??a $\mu$ (e Be?d?? $\mu \mid$ - the clouds of the abyss, or the darkness of the abyss; ?pad |? | Be?d?? what fell to the abyss.

[75] ??e?d) ??d??(?? ? 8s???a? ?? |?? ??d (literally - "I erected a firm foundation and established it above the waters").

${ }^{[76]}$ On the concept of the Foundation Stone cf.: L. Ginzberg, Legends of the Jews (Philadelphia: The Jewish Publication Society of America, 1955) 5.15; E. Burrows, "Some Cosmological Patterns in Babylonian Religion", The Labyrinth (ed. S.H. Hooke; London, 1935) 45-59.; J. Fossum, The Name of God and the Angel of the Lord (WUNT, 36; Tübingen: Mohr/Siebeck, 1985) $250 \mathrm{ff}$.

[77] E. Burrows, "Some Cosmological Patterns in Babylonian Religion", 45-52.

${ }^{[78]}$ E. Burrows, "Some Cosmological Patterns in Babylonian Religion", 46-7.

[79] ?aue??e. Vaillant, 30.

[80] ?aue??e. Vaillant, 32.

$[811$ Andersen, 149.

[82] ?d???|.

[83] ?\}?a ße???a??. Vaillant, 30. It can be also translated as "a great aeon."

[84] ??\%?a?|.

[85] Andersen, 145.

[86] APOT, 2.445.

${ }^{[87]}$ M. Philonenko, "La cosmogonie du 'livre des secrets d'Hénoch'" Religions en Égypte.

Hellénistique et Romaine (Paris: Presses Universitaires de France, 1969) 114.

${ }^{[88]}$ See L. Cry, "Quelques noms d'anges ou d'êtres mysterieux en II Henoch," RB 49 (1940) 201.

[89] Vaillant, xi.

[90] Scholem, Origins of the Kabbalah, 73.

${ }^{[91]}$ G. Scholem, "Die Lehre vom 'Gerechten' in der jüdischen Mystik" Eranos-Jahrbuch 27 (1958) 252.

[92] J.T. Milik, The Books of Enoch. Aramaic Fragments of Qumran Cave 4 (Oxford: Clarendon Press, 1976) 113.

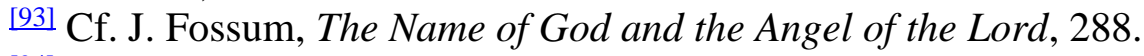

[94] APOT, 2.445.

[95] Vaillant, xi-xii.

[96] Milik, 113.

[97] Andersen, 144-145.

[98] Andersen, 145.

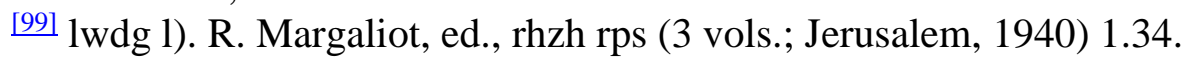

[100] Literally: "there were waters within waters" (Mymb Mym wwh). R. Margaliot, ed., rhzh rps (3 vols.; Jerusalem, 1940) 1.34.

${ }^{[101]}$ H. Sperling and M. Simon (trs.), The Zohar (5 vols.; London and New York: Soncino, 1933) 1.75 .

${ }^{[102]}$ In the majority of MSS this name has a form Adoil (?d??? |) with "o" in the middle of the 
word:

J - Adoil. Andersen, 144.

R - Adoil. Sokolov, 1.25;

P- Adoilju. Sokolov, 1.25;

U - Adoil'. Sokolov, 1.117;

N - Idoil. Vaillant, 28.

B - Adoil'; Idoil'. Sokolov, 1.91;

$\mathrm{B}^{2}$ - Adoil. Sokolov, 1.137;

Chr - Adoil'. Sokolov, 1.150.

[103] Vaillant, 29-30.

[104] Andersen translated it as "extremely large."

[105] The title El gadol, "the great God," can be connected with the term "Great Aeon," which came out from the belly of "Great One,"- Adoil. Compare also Zohar's narrative: "At first there were waters within waters."

${ }^{[106]}$ M. Sokoloff, A Dictionary of Jewish Palestinian Aramaic (Ramat-Gan: Bar Ilan University Press, 1990) 77.

${ }^{[107]}$ M. Sokoloff, A Dictionary of Jewish Palestinian Aramaic (Ramat-Gan: Bar Ilan University Press, 1990) 77.

${ }^{[108]}$ Cf. Gruenwald, Apocalyptic and Merkavah Mysticism, 51.

[109] Andersen, 94. 